\begin{tabular}{|c|c|}
\hline Title & Road Traffic Crashes and Fatalities in Japan 2000-2010 With Special Reference to the Elderly Road U ser \\
\hline Author(s) & Kaimila, Bongani; Y amashina, Hiroko; A rai, A suna; Tamashiro, Hiko \\
\hline Citation & $\begin{array}{l}\text { Traffic injury prevention, 14(8), 777-781 } \\
\text { https://doi.org/10.1080/15389588.2013.774085 }\end{array}$ \\
\hline Issue Date & 2013 \\
\hline DOC URL & http:/hdl.handle.net/2115/57016 \\
\hline Rights & $\begin{array}{l}\text { This is an A uthor's A ccepted Manuscript of an article published in Traffic Injury Prevention, V ol. 14, Iss. 8, 2013, } \\
\text { copyright T Tylor \& Francis, avail lable online at: http://www.tandfonline.com/10.1080/15389588.2013.774085. }\end{array}$ \\
\hline Type & article (author version) \\
\hline File Information & Traffic Inj Prev_14(8)_777-781.pdf \\
\hline
\end{tabular}

Instructions for use 
Title:

\title{
ROAD TRAFFIC CRASHES AND FATALITIES IN JAPAN 2000-2010 WITH SPECIAL REFERENCE TO THE ELDERLY ROAD USER
}

\author{
Authors: \\ Bongani Kaimila, Hiroko Yamashina, Asuna Arai*, Hiko Tamashiro \\ Affiliation: \\ Department of Global Health and Epidemiology \\ Hokkaido University Graduate School of Medicine \\ Kita 15 Nishi 7, Kita-ku, Sapporo, Hokkaido 060-8638, Japan \\ Email Addresses: \\ Bongani Kaimila: bkaimila@yahoo.co.uk \\ Hiroko Yamashina: y-hiroko@med.hokudai.ac.jp \\ Hiko Tamashiro: tamashiro@med.hokudai.ac.jp \\ *Corresponding author: \\ Dr. Asuna Arai \\ asunar@med.hokudai.ac.jp \\ Tel: +81-11-706-5051 \\ Fax: +81-11-706-7374
}




\section{ABSTRACT}

\section{Objective:}

To investigate comparative road-user crash and fatality rates in Japan between 2000-2010 in the elderly and young.

\section{Methods:}

Data from the Japan Ministry of Health, Labour and Welfare Vital Statistics Database and the Institute for Traffic Accident Research and Data Analysis were used to calculate crash rates by age group, vehicle, and license category.

\section{Results:}

Fatal crash rates per 100,000 licensed drivers for four-wheeled motor vehicle drivers decreased by 53\%, $56 \%$ and $42 \%$ among the $65-69,70-74$, and $\geq 75$ age groups between $2000-2010$, respectively, compared with $66 \%$ and $60 \%$ among the 16-19 and 20-24 age groups, respectively. Fatal crash rates per 100,000 licensed riders for two-wheeled motor vehicles decreased by $64 \%, 23 \%$, and $33 \%$ in the $65-69,70-74$, and $\geq 75$ age groups, respectively. Similarly, fatal crash rates per million population among bicyclists and pedestrians decreased in all age groups but were highest in the elderly age group in all years; the annual fatal crash rate for elderly pedestrians was 3 to 10 times higher than that for younger pedestrians.

\section{Conclusions:}

Despite the overall decrease in the elderly crash and fatal crash rates in all road use categories, elderly pedestrians are more susceptible to road traffic crashes and are more likely to be killed than younger persons. Further research may reduce this risk.

\section{Keywords:}

Elderly, Japan, legislation, motor vehicles, pedestrians, traffic accidents 


\section{INTRODUCTION}

Aging is taking place in many countries (WHO 2011) and although this demographic shift is most prominent in Western countries, the proportion of elderly people in low- and middle-income nations is also predicted to increase by the year 2030 (Kinsella et al. 2008). The change in age structure affects a wide range of health and economic issues, and presents novel challenges to countries and society.

Road safety is one of these challenges (OECD 2001; Transportation and Research Board 2001), and the question "how safe is an elderly person on the road?" whether as a vehicle driver, pedestrian, or cyclist presents a challenge that has to be addressed (Braver et al. 2004; Eberhard et al. 1996).

Over the last few decades, road safety in the elderly population has been actively addressed in Japan. With 23.0\% of the Japanese population in 2010 being 65 or over (Japan Statistics Bureau, 2011), Japan has the highest proportion of elderly people in the world (OECD et al. 2011). Furthermore recent data from the National Police Agency showed that since 2003, Japan has administered more licenses to elderly ( $\geq 65$ years) than young (16-24 year old) drivers (Japan National Police Agency 2010).

Several authors have reported concerns and provided evidence that the risk of injury or death from road crashes increases with age. Reports of elderly drivers losing control and killing people (Bowles 2011; Gougis 2003) or of elderly people killed while crossing the road (CBS San Francisco 2012; Chandran and Sousa 2012; Dunn 2012) emphasize the importance of improving road safety for the elderly. Other studies show that age affects a person's ability to make safe decisions on the road, such as when to cross, brake, or make a turn (Campagne et al. 2004; Goode et al. 1998; Lyman et al. 2001; Owsley et al. 1998), and highlight the relationship of age and co-morbidities (Dobbs et al. 2005; Janke et al. 1994) or taking medication (McGwin et al. 2000; Ray et al. 1993). Moreover, Li et al. (2003) showed the likelihood of death or serious injury in crashes increases because fragility increases with age.

Over the past two decades, the Japanese government has sought to reduce serious crash rates by introducing a number of road traffic legislations specifically aimed at elderly drivers. The most recent legislation introduced cognitive screening for drivers aged 75 years or over, as a prerequisite for license renewal. This measure is similar to that introduced in Denmark (Siren et al. 2012), and other countries have introduced other licensing regulations intended to decrease fatal road crashes among elderly drivers (McGwin et al. 2008).

Thus our main objective in this paper is to describe and examine the trends in crash and fatality 
rates for different classes of vehicles and age groups of road users in Japan during 2000-2010 and compare the rates in older and younger age groups.

\section{METHODS}

\section{Data sources}

Data for the age/population structure of Japan from 2000-2010, were obtained from the Japan Ministry of Health, Labour and Welfare (MHLW) Vital Statistics database (Vital Statistics, MHLW). Data for road traffic events during the same period were obtained from the Institute for Traffic Accident Research and Data Analysis (ITARDA) database (Kotsu Tokei, ITARDA). These data include total crashes, fatal crashes, and license holders by age, year, road user, and vehicle category (motorized four-wheeled, motorized two-wheeled, bicycles, pedestrians). We calculated the annual total and fatal crash rates per licensed driver, for each vehicle category, and for different age groups. The age groups were divided into elderly (65-69, $70-74$, and $\geq 75$ years), young (16-19 and 20-24 years), and adult (25-64 years).

The population data categories were obtained from MHLW database; and road user and vehicle categories were obtained from ITARDA and NPA databases. The database categories originally appear in Japanese and were translated into English with special care. From the ITARDA database, the terms 'total crashes', 'fatal crashes' and 'primary party' were translated from Japanese into English and verified with ITARDA and the National Police Agency (NPA) for exactness of the translations. The legislature changes listed in Table.2 were translated into English with special care and verified with the Japan Ministry of Justice for exactness of the translations.

\section{Data analysis}

We used SPSS $19^{\mathrm{TM}}$ (IBM, USA) to calculate and plot frequencies for crash rates (the total in a specific age or user group divided by the total age group population), for different road user categories per licensed driver/rider for each age group and year.

\section{RESULTS}

\section{Motorized four-wheeled vehicle drivers}

Between 2000 and 2010, the proportion of the population aged 65-69, 70-74, and $\geq 75$ years 
increased by $16 \%, 19 \%$ and $58 \%$, respectively. In contrast, the population in the 16-19 and 20-24 age groups decreased by $19 \%$ and $24 \%$, respectively (Table 1). Among those aged 25-34 and 45-59 years, the population decreased, and the population of the 35-44, and 60-64 age groups increased (Table 1).

From 2000-2010, the numbers of licensed drivers for four-wheeled motor vehicles in the three elderly age groups increased by $67 \%, 77 \%$ and $201 \%$; the numbers of younger licensed drivers aged $16-$ 19 and 20-24 years fell by $27 \%$ and $25 \%$, respectively; and the numbers of licensed adult drivers increased, except in the 25-29, 30-34, and 50-54 age groups (Table 1).

The total crash rates (fatal and non-fatal, Table A1) and fatal crash rates (Figures 1 and A1) decreased in all age groups from 2000-2010. Fatal crash rates per licensed driver were highest in the 16-19 followed by the $\geq 75$ age groups. Injury rates resulting from four-wheeled motor vehicle crashes decreased in the elderly age groups.

\section{Motorized two-wheeled motor vehicle riders}

The total crash rates (fatal and non-fatal) per 100,000 licensed riders decreased among the elderly age groups and in the 16-19 and 20-24 age groups (Table A2). Fatal crashes per 100,000 licensed riders decreased in the elderly and the youngest age groups while there was an increase in crash rates for the 2564 age groups (Figure A2).

\section{Bicyclists}

The total crash rates (fatal and non-fatal) among the three elderly groups decreased between 2000 and 2010. In contrast, crash rates increased in younger age groups (Table A3).

Fatal crash rates involving bicycles decreased in all age groups and decreased most in the elderly age groups (Figure 2). However, the annual fatality rate was highest among the elderly.

\section{Pedestrians}

Total pedestrian crash (fatal and non-fatal) rates per 1,000,000 population decreased steadily between 2000 and 2010 across all age groups, although the elderly experienced the highest crash rates throughout this period (Table A4).

Fatal pedestrian road traffic crash rates fell in all age groups between the years 2000 and 2010. The annual fatality rates increase with age (Figure 3), and were highest in the $\geq 75$ age group. Although the annual pedestrian fatality rates declined by $71 \%$ between 2000 and 2010 for the $\geq 75$ age group, the 2010 fatality rate for the same age group was nine times higher than the rate for the 16-19 age group (Figure 3). 


\section{DISCUSSION}

The Japanese population structure has changed over ten years; the elderly population has increased and the proportion of young people has fallen. The $\geq 75$ age group had the highest rate of population increase among all the groups, and this partly explains the increase in licensed drivers in this age group. The changes reflect the ageing of Japan's baby-boomer generation from the country's period of rapid economic growth in the late 1960s and early 1970s and the subsequent rapid increase of automobile use in Japan. We attribute the decrease in the number of young license holders (16-24) to Japan's low fertility rate and decreased population.

Although the number of elderly license holders has increased, the road traffic crash rates for all vehicle classes have decreased, and the elderly persons' crash rate for four-wheeled motor vehicles was lower than that in the younger age groups (Table A1). We attribute a large part of this decrease to the introduction and enforcement of road traffic legislations (Table 2).

Differences in crash rate may also arise because the elderly are more likely to use other types of road transport than younger persons. We note there could be inherent differences in elderly persons who drive, ride, or walk, versus those who do not. Many local governments in Japan subsidize public transport for the elderly by issuing free bus coupons, taxis on demand, or other special transportation arrangements. However, public transport systems targeted at the elderly are still under development and could be improved to better serve the growing elderly population.

The rates of fatal crashes resulting from four-wheeled motors vehicles also vary depending how the population of interest is defined. When the overall population proportion of each age group is considered, there is a decrease in fatality rates in all age groups, and the fatality rate for the elderly was lower than that for younger age groups. This indicates that at the population level, road traffic crash fatalities were less frequent among the elderly than among younger people. However, when the number of licensed drivers per age group is used to calculate fatal crash rates, the highest fatality rates are for elderly age groups. The differences in calculated fatality rates using different sample populations at risk has also been reported from other countries (Eberhard et al. 2005; Hakamies-Blomqvist et al. 2005) and may indicate increased fragility with age instead of increased crash risk (Li et al. 2003).

The rates of two-wheeled motor vehicle crashes per licensed rider were lower among the elderly 
compared with other age groups, although the rates of fatal crashes were the highest. This may show how increased fragility affects the elderly.

However, we also note that the fatal crash rate calculation does not distinguish licensed active drivers from inactive drivers. This may mean that the real risk of fatal crashes among the active elderly differs from the calculated rates. If inactive, self-limiting elderly riders were excluded from the calculation, the real crash rates in the elderly could be higher than those reported here.

Road traffic crash rates among cyclists differ from those calculated for four-wheeled motor vehicles. Total crash rates increased among younger but decreased in the elderly age groups, but fatal crash rates were higher among the elderly cyclists. We offer two possible explanations: elderly cyclists may be more fragile and thus the fatality rates increase with advanced age. Second, transport preferences may change, and elderly persons may be more likely to use bicycles; in this case elderly cyclists are more likely to be involved in fatal crashes.

Although pedestrian crash rates have decreased in all age groups, the rate among elderly pedestrians was higher than that for younger pedestrians. Elderly persons may be at an increased crash risk because of behaviors such as unsafe crossing of roads or ignoring or being unaware of traffic lights. As above, elderly fatality rates are also higher than those of younger people, reflecting increased fragility. The elderly pedestrian total crash rates decreased significantly (Table A4). This may reflect the implementation of safety advocacy and training by local police agencies throughout Japan.

We consider the decreases in crash and fatality rates in all age groups can be attributed to improved road safety awareness, especially among the elderly, enforcement of legislature to combat risky behaviors among road users, and environmental changes to the road environment (better road construction and management, safer vehicle designs). We intend to use these results to assess the effectiveness of elderly driver licensing legislation in Japan and to compare the effectiveness of different international approaches to road traffic safety among the elderly.

\section{LIMITATIONS}

A better measure of risk and crash rates would use the distance travelled per year by each road use category. However, these data were unavailable and we consider that license data indicate vehicle usage and reasonably estimate risk at the group level. 


\section{CONCLUSIONS}

Crash rates for elderly road users in Japan declined between 2000 and 2010, reflecting improvements in road safety in different modes of transportation. However, elderly pedestrians still have a high risk of being involved in road traffic crashes and fatality rates are high. These results indicate that more effort should be made to enhance road safety for elderly pedestrians, especially considering the expected rapid growth in the elderly population. 


\section{REFERENCES}

Bowles S, More older drivers in accidents, USA Today $17^{\text {th }}$ July 2003. Available at: http://www.usatoday.com/news/nation/2003-07-17-older-drivers-usat_x.htm. Accessibility verified December 3, 2012.

Braver ER, Trempel RE. Are older drivers actually at higher risk of involvement in collisions resulting in deaths or non-fatal injuries among their passengers and other road users? Inj Prev. 2004; 10(1): 27-32.

Campagne A, Pebayle T, Muzet A. Correlation between driving errors and vigilance level: influence of the driver's age. Physiol Behav. 2004; 80(4): 515-24.

CBS San Francisco, Elderly pedestrian killed in collision with bicyclist in El Cerrito, CBS San Francisco, 7 June 2012. Available at: http://sanfrancisco.cbslocal.com/2012/06/07/elderly-pedestrian-dies-afterbeing-struck-by-a-cyclist/. Accessibility verified December 3, 2012.

Chandran A, Sousa TR. Road traffic deaths in Brazil: rising trends in pedestrian and motorcycle occupant deaths. Traffic Inj Prev. 2012; 13 (1) (Suppl):11-6.

Dobbs BM, Medical Conditions and Driving: Current Knowledge. Final Report. Association for the Advancement of Automotive Medicine. 2005; DTNH22-94-G-05297, National Highway Traffic Safety Administration, Washington, District of Columbia. Available at: http://www.amaassn.org/ama1/pub/upload/mm/433/older-drivers-chapter9.pdf. Accessibility verified December 3, 2012.

Dunn K. Pedestrian, 89, Dies after being struck by a reversing car in Etobicoke parking lot, The Star $26^{\text {th }}$ June 2012. Available at: http://www.thestar.com/news/gta/article/1217687--pedestrian-89-dies-afterbeing-struck-by-a-reversing-car-in-etobicoke-parking-lot. Accessibility verified December 3, 2012.

Eberhard J. Older drivers' "high per-mile crash involvement": the implications for licensing authorities. Traffic Inj Prev. 2008; 9(4): 284-90.

Eberhard JW. Safe Mobility for Senior Citizens. IATSS Research. 1996; 20(1): 29-37.

Goode KT, Ball KK, Sloane M, Roenker DL, Roth DL, Myers RS, Owsley C. Useful field of view and other neurocognitive indicators of crash risk in older adults. J Clin Psychol Med Settings. 1998; 5 (4): 425-40.

Gougis M. 9 Die, Many Injured, As Driver Plows Into Santa Monica Farmers Market Hitting Wrong Pedal Leads To Catastrophe. Daily News Los Angeles California 17th July 2003. Available at: 
http://www.thefreelibrary.com/9+DIE,+MANY+INJURED,+AS+DRIVER+PLOWS+INTO+SANTA +MONICA+FARMERS+MARKET...-a0105545652. Accessibility verified December 3, 2012.

Hakamies-Blomqvist L, Wiklund M, Henriksson P. Predicting older drivers' accident involvement-Smeed's law revisited. Accid Anal Prev. 2005; 37(4): 675-80.

Institute for Traffic Accident Research and Data Analysis. Kotsu Tokei (in Japanese). Available at: http://www.itarda.or.jp/index.php. Accessibility verified December 10, 2012.

Janke MK. Age-related disabilities that may impair driving and their assessment. California Department of Motor Vehicles, Sacramento, CA.1994; Report No. 156.

Japan National Police Agency. The White Paper on Police 2010. Available at: http://www.npa.go.jp/hakusyo/h22/english/White_Paper_2010.pdf. Accessibility verified December 3, 2012.

Kinsella K. An Ageing World - U.S. Census Bureau. 2008; Available at: http:// www.census.gov/prod/2009pubs/p95-09-1.pdf. Accessibility verified December 3, 2012.

Li G, Braver ER, Chen L-H. Fragility versus excessive crash involvement as determinants of high death rates per vehicle-mile of travel among older drivers. Accid Anal Prev. 2003; 35(2): 227-35.

Lyman JM, McGwin G, Sims RV. Factors related to driving difficulty and habits in older drivers. Accid Anal Prev. 2001; 33(3): 413-21.

McGwin G, Sims RV, Pulley L, Roseman JM. Relations among chronic medical conditions, medications, and automobile crashes in the elderly: a population-based case-control study. Am J Epi. 2000; 152(5): 424-31.

McGwin G. The Impact of a Vision Screening Law on Older Driver Fatality Rates. Arch Ophthalmol. 2008 November; 126(11): 1544-7.

Ministry of Health, Labour and Welfare. Statistics and Information Department, Minister's Secretariat. Vital Statistics. Available at: http://www.mhlw.go.jp/english/database/db-hw/vs01.html. Accessibility verified December 10, 2012.

OECD Ageing and Transport-Mobility Needs and Safety Issues, Organization for Economic Cooperative Development, Paris, France. 2001. Available at: http://www.oecd.org/sti/transport/roadtransportresearch/2675189.pdf.

OECD, “Elderly population by region”, in OECD Factbook 2011-2012: Economic, Environmental and 
Social Statistics, OECD Publishing. 2011. Available at: http://dx.doi.org/10.1787/factbook-2011-12-en. Accessibility verified December 3, 2012.

Owsley C, Ball K, McGwin G, Sloane ME, Roenker DI, White MF, Overley ET. Visual processing impairment and risk of motor vehicle crash among older adults. JAMA. 1998; 279(14): 1083-8.

Ray WA, Thapa PB. Medications and the older driver. Clin Geriatr Med. 1993 May; 9(2): 413-38.

Siren A, Meng A. Cognitive screening of older drivers does not produce safety benefits. Accid Anal Prev. 2012; 45: 634-8.

Transportation Research Board. Transportation in an Aging Society: A Decade of Experience. Available at: http://onlinepubs.trb.org/onlinepubs/conf/reports/cp_27.pdf

WHO, Global Health and Ageing Report. Available at: http://www.who.int/ageing/publications/global_health.pdf. Accessibility verified December 3, 2012. 


\section{TABLES AND FIGURES}

Table 1. Changes in population and number of licensed drivers by age group in Japan between 2000-2010.

\begin{tabular}{|c|c|c|c|c|c|c|}
\hline \multirow{3}{*}{$\begin{array}{l}\text { Age } \\
\text { group }\end{array}$} & \multicolumn{3}{|l|}{ Population } & \multicolumn{3}{|c|}{ License Holders } \\
\hline & \multicolumn{2}{|l|}{ Year } & \multirow{2}{*}{$\begin{array}{l}\% \\
\text { change }^{*}\end{array}$} & \multicolumn{2}{|c|}{ Year } & \multirow{2}{*}{$\begin{array}{l}\text { \% } \\
\text { change* }\end{array}$} \\
\hline & 2000 & 2010 & & 2000 & 2010 & \\
\hline $16-19$ & $7,433,115$ & $6,028,600$ & -18.90 & $1,110,154$ & 813,105 & -26.76 \\
\hline $20-24$ & $8,300,297$ & $6,304,880$ & -24.04 & $6,742,810$ & $5,041,282$ & -25.23 \\
\hline $25-29$ & $9,626,221$ & $7,154,666$ & -25.68 & $8,951,081$ & $6,632,433$ & -25.90 \\
\hline $30-34$ & $8,608,881$ & $8,213,960$ & -4.59 & $8,156,635$ & $7,753,537$ & -4.94 \\
\hline $35-39$ & $7,978,061$ & $9,688,045$ & 21.43 & $7,495,975$ & $9,215,350$ & 22.94 \\
\hline $40-44$ & $7,706,162$ & $8,650,602$ & 12.26 & $6,906,744$ & $8,226,254$ & 19.10 \\
\hline $45-49$ & $8,845,461$ & $7,966,133$ & -9.94 & $7,334,049$ & $7,473,226$ & 1.90 \\
\hline $50-54$ & $10,391,001$ & $7,608,317$ & -26.78 & $8,211,384$ & $6,810,665$ & -17.06 \\
\hline $55-59$ & $8,698,453$ & $8,656,055$ & -0.49 & $5,698,901$ & $7,140,682$ & 25.30 \\
\hline $60-64$ & $7,711,606$ & $10,054,575$ & 30.38 & $4,217,837$ & $7,821,404$ & 85.44 \\
\hline $65-69$ & $7,091,585$ & $8,230,222$ & 16.06 & $3,119,804$ & $5,198,253$ & 66.62 \\
\hline $70-74$ & $5,889,998$ & $6,987,391$ & 18.63 & $1,958,851$ & $3,468,871$ & 77.09 \\
\hline $75+$ & $8,979,838$ & $14,149,539$ & 57.57 & $1,064,812$ & $3,207,621$ & 201.24 \\
\hline
\end{tabular}

Data sources: Population data (Vital Statistics, Ministry of Health Labour and Welfare, Japan), Licensing data (Institute for Traffic Research and Data Analysis, Japan)

* Percent change in licensing rate: 2010 from 2000 
Table 2. Summary of road traffic laws introduced in Japan between 2000 and 2010

\begin{tabular}{|c|c|}
\hline Date & Law \\
\hline April 1, 2000 & Mandatory use of child safety seat until 6 years old \\
\hline \multirow{3}{*}{ June 1, 2002} & $\begin{array}{l}\text { Increased enforcement and higher penalties for risky } \\
\text { driving }\end{array}$ \\
\hline & $\begin{array}{l}\text { 'Age change' for elderly license laws (testing and } \\
\text { mark: } 75 \text { to } 70 \text { years old) }\end{array}$ \\
\hline & "Four leaf clover mark" on cars for disabled drivers \\
\hline November 1, 2004 & $\begin{aligned} \text { Increased enforcement and higher penalties for: } & \\
& >\text { cell phone use } \\
& >\text { alcohol testing }\end{aligned}$ \\
\hline September 19, 2007 & $\begin{array}{l}\text { Increased enforcement and higher penalties for } \\
\text { drunk driving }\end{array}$ \\
\hline June 1, 2008 & $\begin{aligned} \text { Mandatory: } & \\
& >\text { seatbelt for rear seat occupants } \\
> & \text { "autumn leaf mark" use on cars for } \\
& \text { elderly drivers }\end{aligned}$ \\
\hline April 17, 2009 & $\begin{array}{l}\text { Mandatory use of "autumn leaf mark" for elderly } \\
\text { drivers changed to optional (or encouraged) }\end{array}$ \\
\hline June 1, 2009 & $\begin{array}{l}\text { Cognitive impairment screening test for aged } 75 \text { or } \\
\text { over }\end{array}$ \\
\hline
\end{tabular}

Data Sources: Ministry of Justice, Japan 


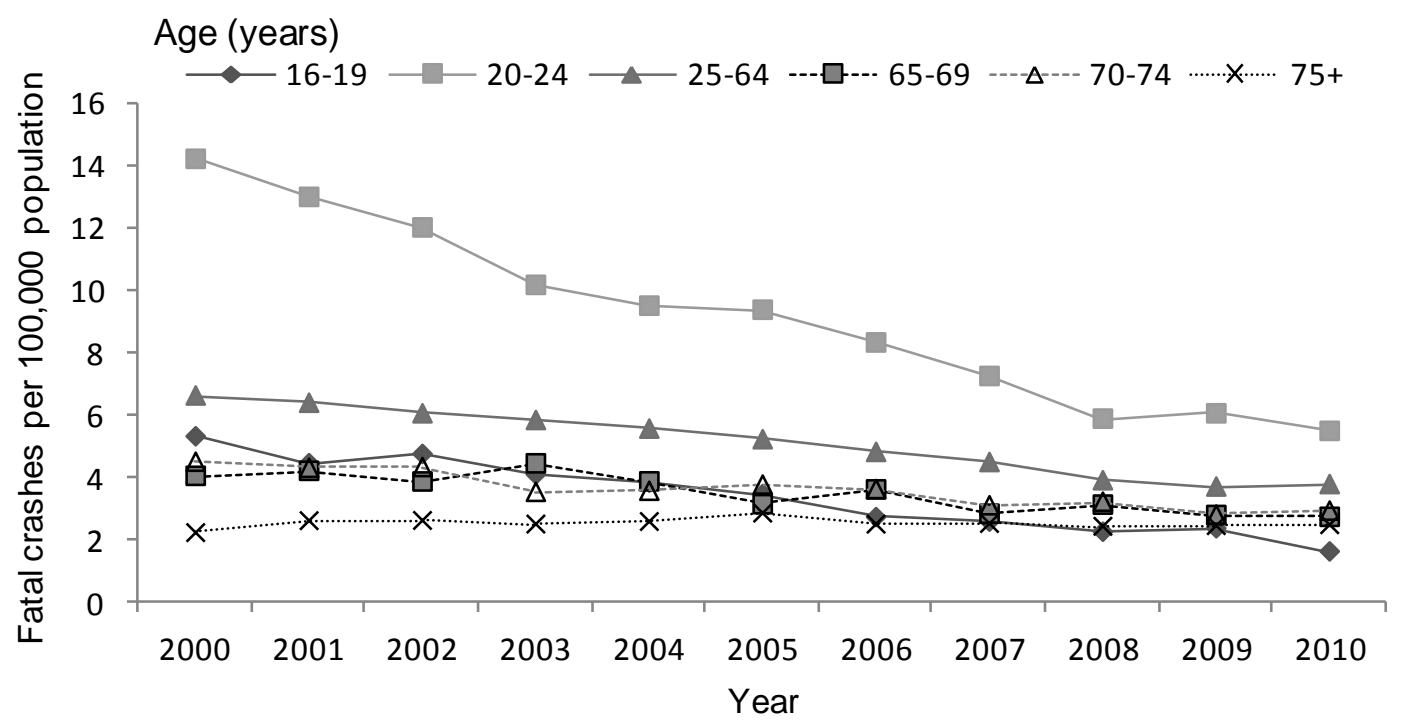

Figure 1. Fatal four-wheeled motor vehicle crashes per 100,000 population among primary party* by age group in Japan, 2000-2010.

Data Sources: Population data (Vital Statistics, Ministry of Health Labour and Welfare, Japan), fatal crash data (Institute for Traffic Research and Data Analysis, Japan)

${ }^{*}$ A person most negligent of those involved in a traffic crash, or, if the level of negligence is almost the same, the least injured party. 


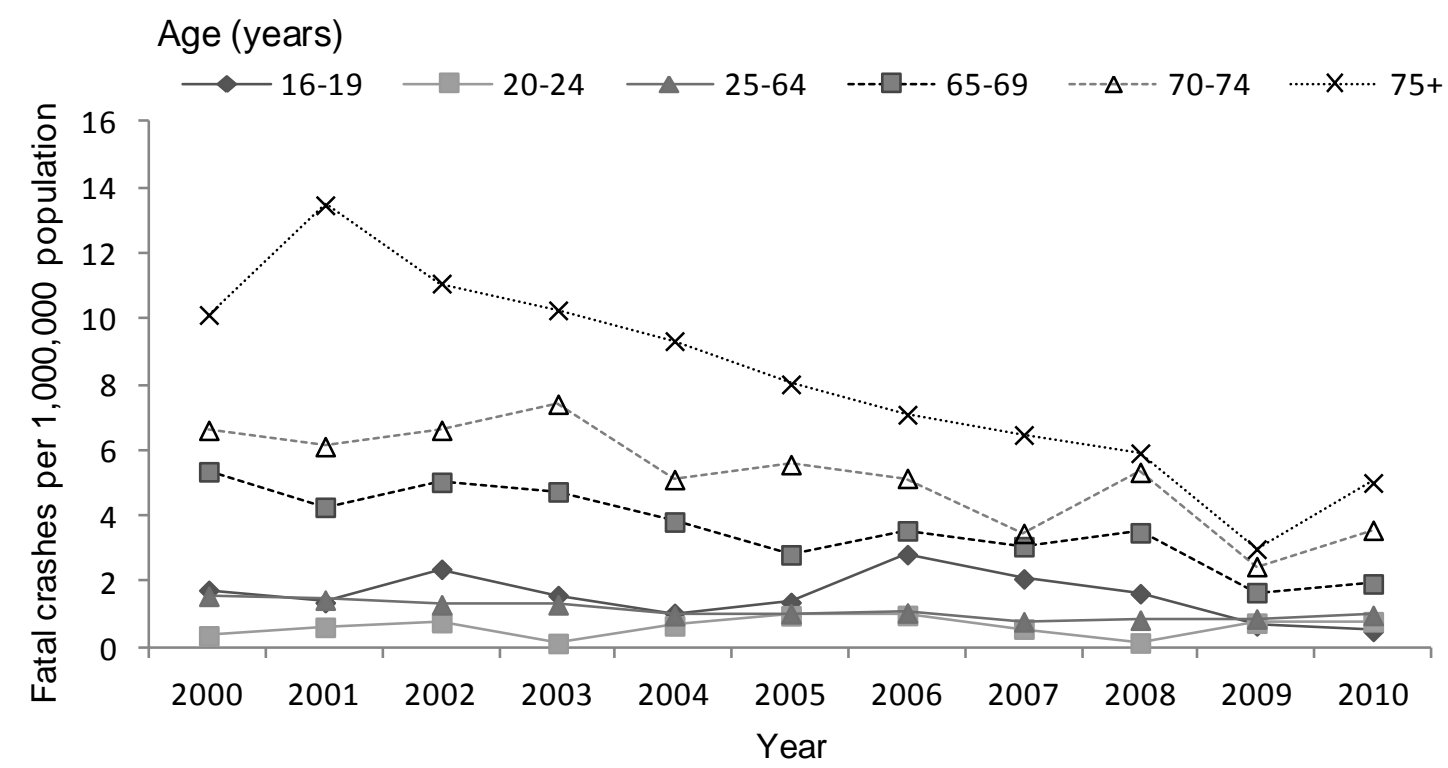

Figure 2. Fatal bicycle crashes per $1,000,000$ population among primary party ${ }^{*}$ by age group in Japan, 2000-2010.

Data Sources: Population data (Vital Statistics, Ministry of Health Labour and Welfare, Japan), fatal crash data (Institute for Traffic Research and Data Analysis, Japan)

${ }^{*}$ A person most negligent of those involved in a traffic crash, or, if the level of negligence is almost the same, the least injured party. 


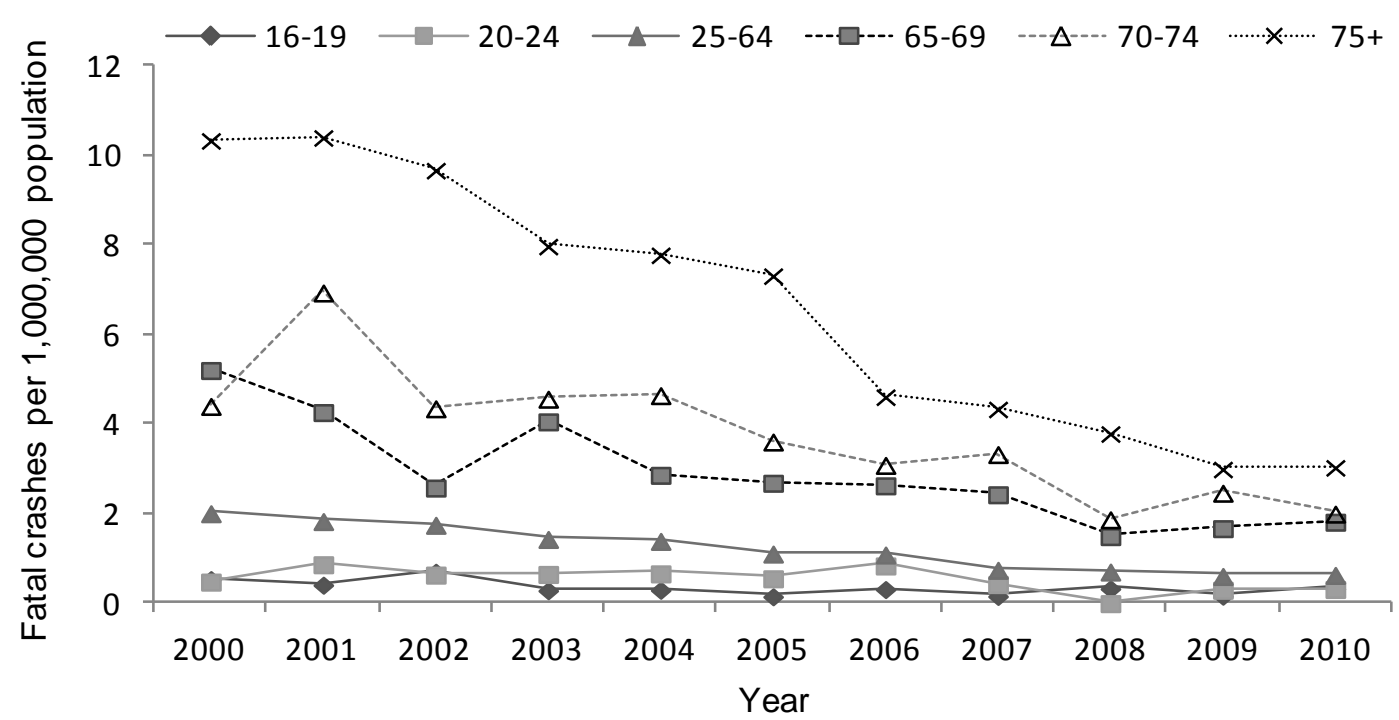

Figure 3. Fatal pedestrian crashes per $1,000,000$ population primary party ${ }^{*}$ by age group in Japan, 2000-2010.

Data sources: Population data (Vital Statistics, Ministry of Health Labour and Welfare, Japan), fatal crash data (Institute for Traffic Research and Data Analysis, Japan)

${ }^{*}$ A person most negligent of those involved in a traffic crash, or, if the level of negligence is almost the same, the least injured party. 


\section{Appendix}

2 Table A1 Four-wheeled motor vehicle crashes per 100,000 licensed drivers among primary party* by age group in Japan, 2000-2010

\begin{tabular}{|c|c|c|c|c|c|c|c|c|c|c|c|c|}
\hline \multirow{2}{*}{$\begin{array}{l}\text { Age } \\
\text { group }\end{array}$} & \multicolumn{11}{|l|}{ Year } & \multirow{2}{*}{$\%$ Change } \\
\hline & 2000 & 2001 & 2002 & 2003 & 2004 & 2005 & 2006 & 2007 & 2008 & 2009 & 2010 & \\
\hline $16-19$ & 3239 & 3202 & 3124 & 3163 & 3105 & 3004 & 2835 & 2732 & 2493 & 2434 & 2391 & -26.2 \\
\hline $20-24$ & 1918 & 1887 & 1812 & 1823 & 1789 & 1772 & 1689 & 1577 & 1425 & 1399 & 1391 & -27.5 \\
\hline $25-29$ & 1365 & 1387 & 1331 & 1320 & 1299 & 1246 & 1181 & 1076 & 992 & 975 & 975 & -28.6 \\
\hline $30-34$ & 1056 & 1056 & 1070 & 1075 & 1070 & 1035 & 975 & 890 & 805 & 778 & 773 & -26.8 \\
\hline $35-39$ & 902 & 961 & 922 & 957 & 968 & 956 & 879 & 823 & 763 & 731 & 735 & -18.5 \\
\hline $40-44$ & 903 & 924 & 897 & 919 & 916 & 894 & 871 & 789 & 732 & 717 & 726 & -19.6 \\
\hline $45-59$ & 932 & 933 & 913 & 916 & 914 & 891 & 838 & 772 & 712 & 683 & 679 & -27.2 \\
\hline $50-54$ & 955 & 982 & 981 & 975 & 969 & 929 & 875 & 810 & 727 & 693 & 682 & -28.6 \\
\hline $55-59$ & 1110 & 1101 & 1017 & 1021 & 995 & 963 & 929 & 893 & 814 & 764 & 731 & -34.1 \\
\hline $60-64$ & 1057 & 1042 & 1037 & 1015 & 1026 & 1032 & 956 & 872 & 811 & 759 & 727 & -31.2 \\
\hline $65-69$ & 1024 & 1040 & 1025 & 1035 & 1021 & 992 & 929 & 894 & 810 & 783 & 790 & -22.9 \\
\hline $70-74$ & 1015 & 1036 & 1018 & 1018 & 1037 & 1025 & 984 & 942 & 882 & 843 & 820 & -19.2 \\
\hline $75+$ & 1190 & 1174 & 1177 & 1180 & 1200 & 1177 & 1113 & 1072 & 1007 & 1012 & 968 & -18.7 \\
\hline
\end{tabular}

3

4 Data sources: Licensing data and crash data (Institute for Traffic Research and Data Analysis, Japan)

$5 \quad$ * A person most negligent of those involved in a traffic crash, or, if the level of negligence is almost the same, the least injured party.

$6 \quad * *$ Percent change in rates: 2010 from 2000 
2 Table A2 Two-wheeled motor vehicle crashes per 100,000 licensed riders among primary party* by age group in Japan, 2000-2010

\begin{tabular}{lrrrrrrrrrrrr}
\hline $\begin{array}{l}\text { Age } \\
\text { group }\end{array}$ & \multicolumn{1}{l}{ Year } & \multicolumn{1}{c}{ 2000 } & 2001 & \multicolumn{1}{c}{2002} & 2003 & 2004 & 2005 & 2006 & 2007 & 2008 & 2009 & 2010 \\
\hline $\mathbf{1 6 - 1 9}$ & 2552 & 2599 & 2590 & 2521 & 2634 & 2610 & 2562 & 2695 & 2542 & 2445 & 2354 & -7.75 \\
$\mathbf{2 0 - 2 4}$ & 4293 & 4340 & 4414 & 4431 & 4587 & 4617 & 4414 & 4534 & 4097 & 4016 & 3762 & -12.37 \\
$\mathbf{2 5 - 2 9}$ & 5722 & 5679 & 5659 & 5319 & 5445 & 5099 & 4733 & 4381 & 3815 & 3750 & 3613 & -36.86 \\
$\mathbf{3 0 - 3 4}$ & 4863 & 5115 & 5493 & 5585 & 5775 & 5511 & 5109 & 4866 & 4221 & 3808 & 3561 & -26.76 \\
$\mathbf{3 5 - 3 9}$ & 3688 & 4023 & 4376 & 4712 & 5069 & 5333 & 5148 & 4957 & 4650 & 4278 & 3795 & 2.91 \\
$\mathbf{4 0 - 4 4}$ & 2709 & 3052 & 3351 & 3518 & 3924 & 4219 & 4325 & 4381 & 4060 & 4159 & 4052 & 49.55 \\
$\mathbf{4 5 - 4 9}$ & 1653 & 2001 & 2211 & 2550 & 2849 & 3381 & 3318 & 3492 & 3635 & 3398 & 3359 & 103.16 \\
$\mathbf{5 0 - 5 4}$ & 1072 & 1210 & 1366 & 1556 & 1753 & 1888 & 2069 & 2265 & 2416 & 2577 & 2672 & 149.25 \\
$\mathbf{5 5 - 5 9}$ & 841 & 882 & 953 & 986 & 1129 & 1184 & 1213 & 1338 & 1391 & 1405 & 1495 & 77.71 \\
$\mathbf{6 0 - 6 4}$ & 689 & 670 & 726 & 724 & 774 & 844 & 829 & 848 & 833 & 892 & 872 & 26.68 \\
$\mathbf{6 5 - 6 9}$ & 719 & 688 & 711 & 690 & 693 & 684 & 699 & 690 & 617 & 607 & 643 & -10.56 \\
$\mathbf{7 0 - 7 4}$ & 759 & 766 & 750 & 721 & 722 & 763 & 729 & 753 & 698 & 651 & 646 & -14.97 \\
$\mathbf{7 5 +}$ & 1067 & 1045 & 973 & 1015 & 1008 & 1003 & 936 & 940 & 929 & 913 & 902 & -15.51 \\
\hline
\end{tabular}

3

4 Data sources: Licensing data and crash data (Institute for Traffic Research and Data Analysis, Japan)

$5 \quad$ * A person most negligent of those involved in a traffic crash, or, if the level of negligence is almost the same, the least injured party.

$6 \quad * *$ Percent change in rates: 2010 from 2000 
2 Table A3 Bicycle crashes per 1,000,000 population among primary party* by age group in Japan, 2000-2010

\begin{tabular}{lrrrrrrrrrrrr}
\hline $\begin{array}{l}\text { Age } \\
\text { group }\end{array}$ & \multicolumn{1}{l}{ Year } & \multicolumn{1}{c}{2000} & 2001 & 2002 & 2003 & 2004 & 2005 & 2006 & 2007 & 2008 & 2009 & 2010 \\
\hline $\mathbf{1 6 - 1 9}$ & 600 & 566 & 578 & 583 & 635 & 645 & 655 & 673 & 656 & 628 & 665 & 10.96 \\
$\mathbf{2 0 - 2 4}$ & 212 & 194 & 206 & 220 & 252 & 272 & 271 & 272 & 291 & 290 & 294 & 38.83 \\
$\mathbf{2 5 - 2 9}$ & 126 & 120 & 127 & 133 & 154 & 159 & 166 & 173 & 178 & 179 & 167 & 31.89 \\
$\mathbf{3 0 - 3 4}$ & 103 & 99 & 102 & 111 & 127 & 123 & 130 & 135 & 125 & 122 & 122 & 18.53 \\
$\mathbf{3 5 - 3 9}$ & 99 & 93 & 99 & 107 & 124 & 128 & 120 & 123 & 125 & 119 & 113 & 14.93 \\
$\mathbf{4 0 - 4 4}$ & 84 & 78 & 97 & 100 & 117 & 121 & 123 & 117 & 126 & 112 & 106 & 26.73 \\
$\mathbf{4 5 - 4 9}$ & 102 & 85 & 93 & 96 & 105 & 111 & 109 & 111 & 109 & 102 & 102 & 0.07 \\
$\mathbf{5 0 - 5 4}$ & 117 & 110 & 120 & 122 & 129 & 126 & 119 & 113 & 103 & 96 & 96 & -17.36 \\
$\mathbf{5 5 - 5 9}$ & 145 & 133 & 143 & 135 & 141 & 142 & 132 & 132 & 123 & 110 & 99 & -31.79 \\
$\mathbf{6 0 - 6 4}$ & 184 & 163 & 166 & 175 & 189 & 177 & 169 & 153 & 146 & 132 & 112 & -38.85 \\
$\mathbf{6 5 - 6 9}$ & 212 & 189 & 200 & 211 & 226 & 205 & 204 & 195 & 164 & 156 & 147 & -30.80 \\
$\mathbf{7 0 - 7 4}$ & 207 & 196 & 206 & 210 & 230 & 231 & 223 & 222 & 202 & 191 & 165 & -20.20 \\
$\mathbf{7 5 +}$ & 210 & 196 & 196 & 191 & 204 & 186 & 182 & 181 & 166 & 159 & 149 & -29.14 \\
\hline
\end{tabular}

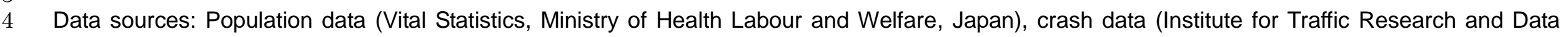

$5 \quad$ Analysis, Japan)

$6{ }^{*}$ A person most negligent of those involved in a traffic crash, or, if the level of negligence is almost the same, the least injured party.

$7 \quad$ ** Percent change in rates: 2010 from 2000 
2 Table A4 Pedestrian crashes per 1,000,000 population among primary party by age group in Japan, 2000-2010

\begin{tabular}{lccccccccccrcr}
\hline $\begin{array}{l}\text { Age } \\
\text { group }\end{array}$ & \multicolumn{1}{l}{ Year } & $\mathbf{2 0 0 0}$ & 2001 & 2002 & 2003 & 2004 & 2005 & 2006 & 2007 & 2008 & 2009 & 2010 & \%Change \\
\hline $\mathbf{1 6 - 1 9}$ & 27.98 & 19.38 & 21.78 & 17.63 & 16.75 & 15.33 & 15.28 & 12.42 & 12.02 & 12.50 & 9.45 & -66.21 \\
$\mathbf{2 0 - 2 4}$ & 30.48 & 29.98 & 26.57 & 21.95 & 21.45 & 19.32 & 18.83 & 17.51 & 12.66 & 11.08 & 11.58 & -62.01 \\
$\mathbf{2 5 - 2 9}$ & 23.37 & 21.76 & 21.65 & 20.10 & 16.15 & 15.44 & 15.66 & 15.22 & 12.06 & 12.38 & 10.06 & -56.95 \\
$\mathbf{3 0 - 3 4}$ & 22.19 & 19.38 & 17.76 & 16.73 & 15.17 & 13.45 & 13.14 & 12.34 & 8.31 & 8.46 & 8.52 & -61.59 \\
$\mathbf{3 5 - 3 9}$ & 22.31 & 17.19 & 18.27 & 17.59 & 14.01 & 15.01 & 13.32 & 13.32 & 10.51 & 8.39 & 7.54 & -66.23 \\
$\mathbf{4 0 - 4 4}$ & 20.89 & 18.71 & 16.67 & 17.85 & 14.15 & 15.18 & 13.40 & 11.03 & 9.82 & 8.78 & 6.70 & -67.91 \\
$\mathbf{4 5 - 4 9}$ & 20.35 & 17.30 & 17.00 & 15.32 & 17.14 & 14.90 & 12.26 & 12.34 & 9.40 & 7.92 & 7.91 & -61.14 \\
$\mathbf{5 0 - 5 4}$ & 26.47 & 25.58 & 22.59 & 21.84 & 17.45 & 16.01 & 13.20 & 12.43 & 11.12 & 9.80 & 7.36 & -72.19 \\
$\mathbf{5 5 - 5 9}$ & 33.11 & 28.04 & 26.03 & 23.37 & 21.60 & 17.90 & 19.53 & 12.45 & 10.55 & 10.37 & 10.05 & -69.64 \\
$\mathbf{6 0 - 6 4}$ & 37.35 & 31.73 & 26.67 & 22.75 & 23.12 & 23.10 & 17.30 & 13.90 & 13.70 & 10.15 & 10.74 & -71.24 \\
$\mathbf{6 5 - 6 9}$ & 39.91 & 33.66 & 30.77 & 32.55 & 25.98 & 23.44 & 19.12 & 20.26 & 15.50 & 13.67 & 12.88 & -67.73 \\
$\mathbf{7 0 - 7 4}$ & 41.77 & 37.09 & 30.04 & 30.61 & 25.92 & 24.42 & 21.66 & 20.60 & 19.49 & 19.62 & 14.17 & -66.08 \\
$\mathbf{7 5 +}$ & 54.01 & 46.95 & 39.76 & 35.29 & 35.90 & 30.01 & 24.34 & 23.54 & 19.51 & 17.86 & 15.90 & -70.56 \\
\hline
\end{tabular}

3

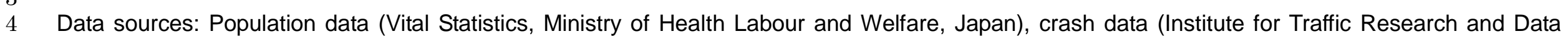

5 Analysis, Japan)

$6 \quad{ }^{*}$ A person most negligent of those involved in a traffic crash, or, if the level of negligence is almost the same, the least injured party.

$7 \quad$ ** Percent change in rates: 2010 from 2000 
Age (years)

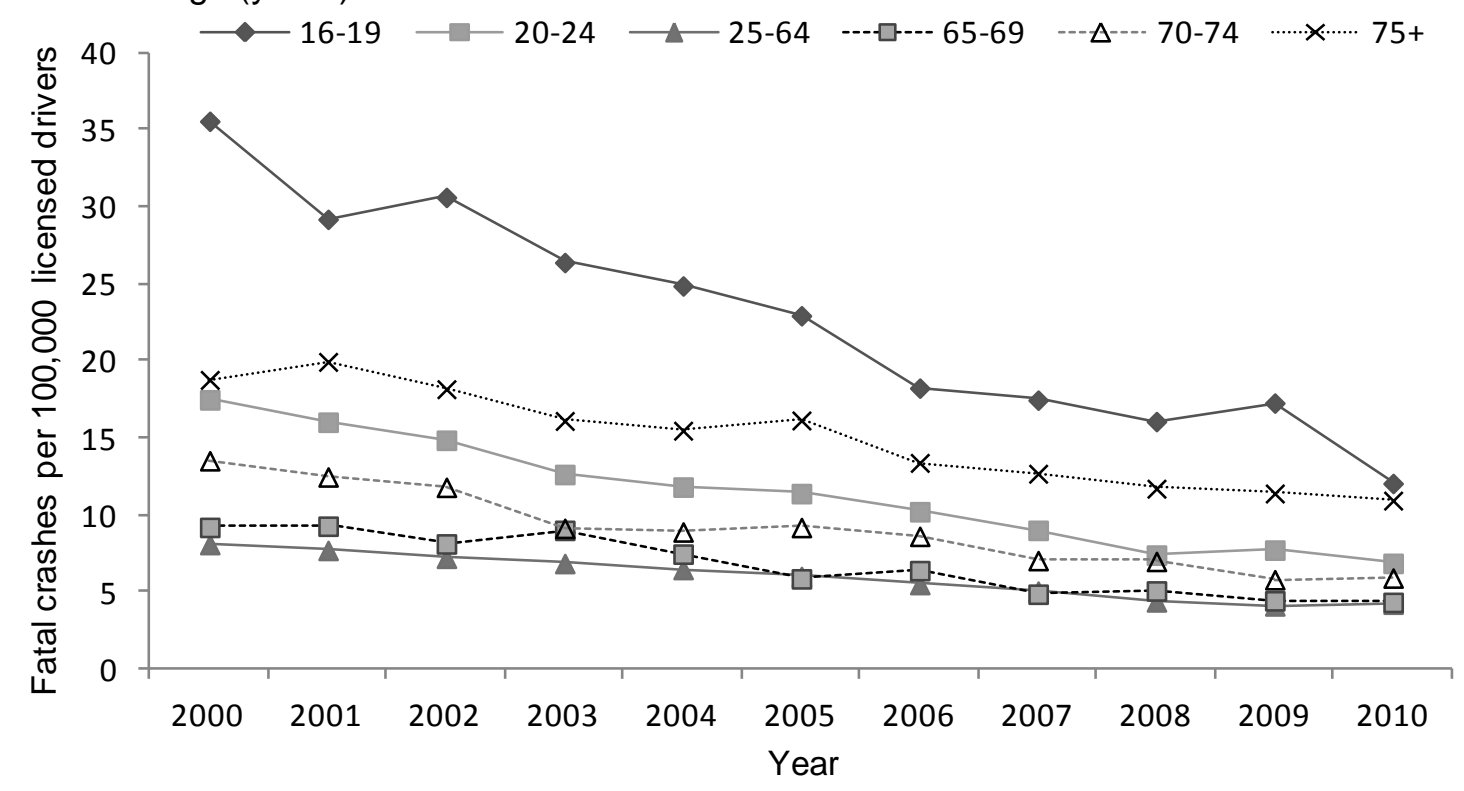

2
3

Figure A1 Fatal four-wheeled motor vehicle crashes per 100,000 licensed drivers among primary

4 party ${ }^{*}$ by age group in Japan, 2000-2010

5 Data Sources: Licensing data and fatal crash data (Institute for Traffic Research and Data

6 Analysis, Japan)

$7 \quad$ * A person most negligent of those involved in a traffic crash, or, if the level of negligence is

8 almost the same, the least injured party. 


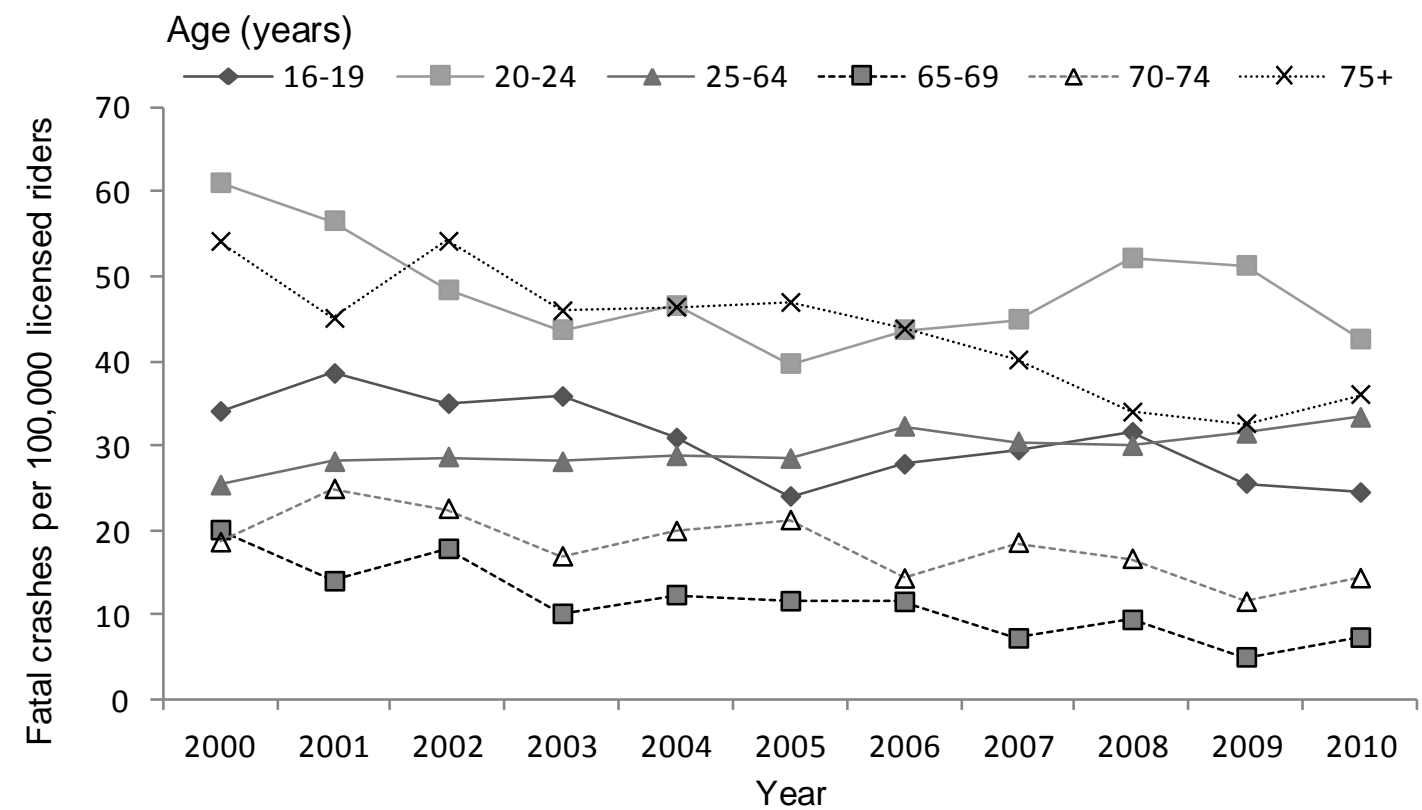

3 Figure A2 Fatal two-wheeled motor vehicle crashes per 100,000 licensed riders among primary

4 party* by age group in Japan, 2000-2010

5 Data Sources: Licensing data and fatal crash data (Institute for Traffic Research and Data,

6 Japan)

$7 \quad$ * A person most negligent of those involved in a traffic crash, or, if the level of negligence is 8 almost the same, the least injured party. 